\title{
Josef Seifert
}

De Veritate - Über die Wahrheit

Band 2: Der Streit um die Wahrheit. Wahrheit und Wahrheitstheorien 



\section{Realistische Phänomenologie:}

Philosophische Studien der Internationalen Akademie für

Philosophie im Fürstentum Liechtenstein und an der

Pontificia Universidad Católica de Chile en Santiago/

\section{Realist Phenomenology:}

Philosophical Studies of the International Academy for Philosophy in the Principality of Liechtenstein and at the Pontificia Universidad Católica de Chile en Santiago

\section{Band IV.2/Volume IV.2}

EDITORS

Professor Juan-Miguel Palacios

With

Professor John F. Crosby and

Professor Czesław Porębski

ASSISTANT EDITORS

Dr. Cheikh Mbacké Gueye

Dr. Matyas Szálay

EDITORIAL BOARD

Professor Rocco Buttiglione, Rom, Italy

Professor Martin Cajthaml, Olomouc, Czech Republic

Professor Carlos Casanova, Santiago de Chile

Professor Juan-José García Norro, Madrid, Spain

Professor Balázs Mezei, Budapest, Hungary

Professor Giovanni Reale, Milan, Italy

Professor Rogelio Rovira, Madrid, Spain

Professor Josef Seifert, Principality of Liechtenstein and Santiago de Chile

Professor Tadeusz Styczeî, Lublin, Poland 


\author{
Josef Seifert
}

\title{
De Veritate - Über die Wahrheit
}

\author{
Wahrheit und Wahrheitstheorien \\ Band 2: Der Streit um die Wahrheit
}

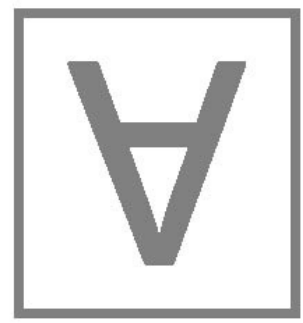

ontos

verlag 


\title{
Bibliographic information published by the Deutsche Nationalbibliothek
}

The Deutsche Nationalbibliothek lists this publication in the Deutsche Nationalbibliografie; detailed bibliographic data are available in the Internet at http://dnb.d-nb.de.

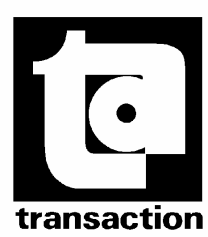

\author{
North and South America by \\ Transaction Books \\ Rutgers University \\ Piscataway, NJ 08854-8042 \\ trans@transactionpub.com
}

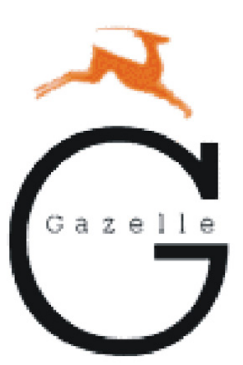

United Kingdom, Ireland, Iceland, Turkey, Malta, Portugal by

Gazelle Books Services Limited

White Cross Mills

Hightown

LANCASTER, LA1 4XS

sales@gazellebooks.co.uk

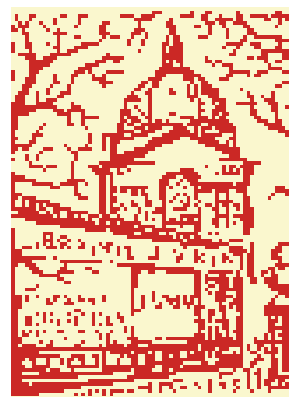

Livraison pour la France et la Belgique:

Librairie Philosophique J.Vrin

6 , place de la Sorbonne; F-75005 PARIS

Tel. +33 (0)1 43540347 ; Fax +33 (0)1 43544818

www.vrin.fr

(C)2009 ontos verlag

P.O. Box 15 41, D-63133 Heusenstamm

www.ontosverlag.com

ISBN 978-3-86838-026-2

ISBN des zweibändigen Gesamtwerks: 978-3-86838-027-9

2009

No part of this book may be reproduced, stored in retrieval systems or transmitted in any form or by any means, electronic, mechanical, photocopying, microfilming, recording or otherwise without written permission from the Publisher, with the exception of any material supplied specifically for the purpose of being entered and executed on a computer system, for exclusive use of the purchaser of the work

Printed on acid-free paper

This hardcover binding meets the International Library standard

Printed in Germany

by buch bücher $\mathbf{d d}$ ag 
Herzlich gewidmet meiner geliebten Tochter Maria Michaela Seifert, deren philosophischer Eros, Liebe zur Wahrheit und erfolgreiche Lehre und Forschung auf dem Gebiet der Philosophie eine Quelle großer Frende für mich sind.

Josef Seifert 